\title{
Gaining a Foothold: How Housing and Belonging Support Youth-at-Risk in Getting a Grip on Adulthood
}

\author{
Ellen Andvig1, Karol Svanoe'2, Marit Borg1 \\ ${ }^{1}$ Faculty of Health Sciences, Buskerud and Vestfold University College, Campus Drammen, Drammen, Norway \\ ${ }^{2}$ Faculty of Health Sciences, Buskerud and Vestfold University College, Campus Vestfold, Horten, Norway \\ Email: ellen.andvig@hbv.no
}

Received 22 October 2015; accepted 10 January 2016; published 15 January 2016

Copyright (C) 2016 by authors and Scientific Research Publishing Inc.

This work is licensed under the Creative Commons Attribution International License (CC BY).

http://creativecommons.org/licenses/by/4.0/

(c) (i) Open Access

\section{Abstract}

In Norway the majority of youth lives under favourable conditions with a remnant of youth-at- risk. Difficulties include school dropout, mental health issues, and homelessness. Several government programs purpose to assist youth-at-risk in becoming independent adults. Project "Good Start" aimed at assisting youth-at-risk to find housing, employment or schooling, and affirmative activities. The aim of this study was to describe and interpret the experiences of project participants. The research methodology had a phenomenological-hermeneutic approach. Individual qualitative interviews were applied with 12 participants. Phenomenological-hermeneutic analysis of the data resulted in five major themes: a safe and secure haven, autonomy and responsibility, a variety of friendships, helpful others and meaningful activities. A metaphor of gaining a foothold on a rock-filled road to adulthood was developed as the overarching theme, with the intention of expressing a holistic understanding of the meaning of the texts. By obtaining stable housing with necessary support, participants (re)established contact with school and work, friends and family. They evolved an identity and envisioned a hope of establishing themselves on their own. Additionally, a sense of belonging, supportive professional relationships, and meaningful activities emerged as vital factors for social participation. Findings confirm positive connections among health, quality of living, and housing, and support the importance of focusing on external living conditions, rather than on individual deviations and diagnoses. Services for youth-at-risk must be developed together with them and issues of safety, security and privacy prioritized; mental health and social services should be coordinated with a long-term perspective. They need support from persons they know and trust, such as mental health nurses, and may require further assistance in developing skills in everyday living. The advantages and disadvantages of housing several youthat-risk in close vicinity need to be assessed. Various housing choices should be available. 


\section{Keywords}

\section{Youth-at-Risk, Housing, Support, Belonging, Emerging Adulthood, Social Participation}

\section{Introduction}

Late adolescence is a tempestuous period with countless changes, as young people traverse towards adulthood. "Emerging adulthood", as Arnett \& Hughes [1] term the age between 18 and 25, is the period between adolescence and adulthood, filled with exploration and self-focus. Youth in the new millennium tend to leave their home-of-origin later, and many are prone to return a second time [2]. The median age for education completion, full-time employment, marriage and child-bearing has also risen [1] [3].

The picture in Norway differs only slightly. Adolescents of the present generation are regarded as well-adjusted and home-loving [4]. Norwegian society is characterised by high economic welfare and security [5]. The majority of its youth live under favourable conditions. According to an annual survey of Norwegian youth [4], the extent of juvenile crime, substance abuse and violence has decreased, truancy has reduced, and far more youth report satisfaction with their parents, residing home longer. Home has increasingly become the chosen "space" for teenagers, as social media make it possible to remain home while retaining contact with friends. Moreover, home ranks highly as a popular spot for meeting peers.

Despite positive living conditions, a remnant of youth-at-risk remains. One can define youth-at-risk as those experiencing complex difficulties, necessitating services from at least two public agencies [6]. One agency that stands out in risk statistics is Child Welfare Services. The transition from public care to independent adult living and/or the unforeseen moves from the home of origin increases risk of psychosocial problems [6]. Many who turn to public services for assistance experience these agencies as unsatisfactory and poorly coordinated [7]-[9]. Lacking support from trustworthy adults can augment the chance of homelessness [10].

Peer impact during adolescent development is also crucial. Homeless young adults rely extensively on friends for support outside the home. Peer relationships during adolescence include individuals, groups, same-sex and opposite-sex relationships and can be constructive or destructive for the developmental journey [11].

School dropout rates are another risk factor. Societal demands necessitate a university degree in order to access good jobs [3]. Despite this fact, school dropout rates remain high. A lack of education contributes to adverse life-course consequences, e.g., poor health and demands on social welfare entitlements [7] [12]. As many as one-third of the youth in Norway do not complete high school within a five-year span [4].

Norwegian Social Research (NOVA) [4] despite its overall optimism, reports an increase in mental health issues. In particular, stress, anxiety and depressive symptoms appear widespread. If this coincides with conflicts in the home or inadequate social support, a risk of mental illness increases. Curtis et al. [13] surmise in a review that there exists a link between the risk of mental illness for young people and local community problems of material poverty, poor living conditions and social stressors, such as violence and victimization.

Emerging adulthood is also a phase with expectations to move out on one's own. A place to live becomes transformed into a home when we alter it to become uniquely ours, giving it emotional and psychological significance [14]. Saunders [15] emphasizes that the home plays a central role in people's minds, especially in relation to their sense of existential security. Youth-at-risk, however, are more susceptible to suffering vagrancy [16]. "Homelessness" can be defined as relying on friends or family for overnighting in order to not have to sleep rough, or spend more than a week in a bed and breakfast, refuge or other contingency accommodation ([17], p. 94). Norway, too, has experienced a rise in homeless youth [10]. In 2008, one fourth homeless was under the age of 24. More than half experienced substance abuse and $25 \%$ had unmet needs for professional support with housing issues [10]. Hodgson et al. [18] suggest the existence of a reciprocal link between mental health problems and homelessness. Supporting such youth can reduce homeless incidences. Wade \& Dixon [19] found that suitable housing was the factor most closely associated with positive mental well-being in young people, surpassing contributions made by education and training.

This ties in with theories of social determinants of health, i.e., the conditions in which people are born, grow, live, work and age, and how these affect one's physical and mental health [20]. Affirmative connections exist among health, quality of living, and housing, which again parallels the understanding of health [21]. It empha- 
sizes that material conditions, such as housing and economy, stimulate increased quality of living and improved health. Such thinking implies a social perspective on health, with focus on external living conditions, rather than on individual deviations and diagnoses. WHO [22] follows this train of thought and has developed a policy framework outlining people-centred health care. People-centred health care is based upon commonly held values and principles, such as "human rights and dignity *.. participation and empowerment” ([22], p 21).

"Emerging adulthood" can thus be applied when describing the same time frame for youth-at-risk, striving to gain a foothold on a bouldered life path. Housing can spur belonging and a sense of security [23] [24]. Fields' [25] research supports positive connections between health and housing; she furthermore claims that the sense of belonging to a community, be that a specific geographic location or simply shared values, is also vital to defining the adult self. Similarly, Arnett [26] alleges that an important aspect of emerging adulthood is social participation and citizenship. Moreover, the European Charter on Participation ([27], p. 21) embraces increased youth participation: "the right, the means $\cdots$ and where necessary the support to participate $\cdots$ so as to contribute to building a better society”.

Several initiatives and programs have been introduced in order to assist youth-at-risk in becoming independent adults. Project "Good Start” is one of them.

\section{Project "Good Start"}

This government project took place in a mid-sized Norwegian municipality (21,000 inhabitants) from July 2010 to June 2013. The municipality received a grant from the Norwegian State Housing Bank to conduct the project [28].

To become a participant in the project, one had to fall within a definition of "youth at risk", i.e., that the person was in need of assistance and supervision to obtain housing, education, work and affirmative recreational activities.

A primary aim of the project was to empower youth/young adults to establish independent adult lives in independent housing. Another aim was to gain experience with improved coordination of public services. The fundamental content of the project was to improve the organization of these services, i.e., their organization in relationship to each individual youth. Rather than youth visiting five offices, one meeting was set up where all five offices were represented. Youth were followed up in finding housing, employment or schooling, and affirmative activities. Several also received assistance in attaining outpatient mental health/substance abuse referrals. The leader held monthly meetings with representatives from High School Follow-up Teams, Mental Health and Substance Abuse Services, Children's Services, and Employee Assistance Services.

There were 20 participants in the project all together. Ten of the 20 moved into a new housing complex in November 2013 and guaranteed a three-year housing contract. Two others received assistance in locating a flat on the open market. By April 2014, ten of the twelve were either employed (1), in training (6), or attending school (3). The majority (11) received public housing aid, mental health nursing and economic assistance. Multi-agency "responsibility groups" were established for six participants.

The aim of the study was to describe and interpret the experiences of the participants in gaining a foothold on adult living.

The research questions were:

- How can informants' experiences of independent living be described?

- How do informants express a growth towards community participation?

\section{Methodology}

The research method chosen for this study rested on a phenomenological-hermeneutic approach, in which the phenomena of the experiences of the participants are the subjects of the research. It seeks to understand the life events of individuals from their own point of view [29]. Descriptions are further refined through a process of interpretation, which can be understood as a movement between understanding and explanation, and between events and meaning [30].

\subsection{Participants}

Twelve of the 20 project participants were included in this study. They were between 18 and 23 years old. They 
had several challenging life situations, many of them with mental health and abuse issues. The majority had completed the obligatory 10 years of education, only one had finished high school. About half of them had lived in foster home or youth group house, the other half came from their parents` home with several health and social problems. Most of them were on work assessment allowance or social welfare benefits, and two had part-time work.

\subsection{Qualitative Interviews}

Individual qualitative interviews were employed. This interview variety seeks to obtain information about an individual's subjective experiences [31]. A thematic interview guide was used concerning questions about how participation in the project influenced their life situation, what expectations and experiences they had concerning contact with project staff members, involvement in planning, contact with other participants. Other questions concerned experiences about work, school, recreational activities, friends and mental health. They were also asked about experiences after having moved in their new home and their relationship to staff, to others living there, to family and friends.

Interviewers were the first and the second authors. Interviews lasted from 30 - 90 minutes, with most taking an hour. Interviews took place in the local Health Care Center, offices on the building site, or in participants' new flats.

The data collection consisted of two phases. In phase one (June 2012 to June 2013), ten youth were interviewed, six men and four women. In phase two (January to April 2014), seven youth were interviewed, two females and five males. The reasons for this diversity are that some of the participants from the first phase dropped out, while some came in at a later date. Thus, two of the participants in phase two had not been interviewed previously; they were interviewed in round two. Five youth were interviewed twice, so as to discern differences in expectations before and after their move into the flats.

\subsection{Analysis}

The phenomenological hermeneutic method of Lindseth and Norberg [32] was utilized to analyse transcribed material. Their method of text analysis is based on Ricoeur's [30] theory of interpretation. The analytical steps are first to gain an intuitive understanding of the entire text through iterated naive readings, seeking to grasp the intuitive sense of the meaning of the text as a whole. The second step is to explain the text through a structural analysis by identifying meaning units, condensing them by formulating sub-themes and themes. Finally, a comprehensive understanding of the whole text is formulated through critical reflection on findings from previous steps.

\subsection{Ethics}

In accordance with the Personal Data Act and Health Register Act, the Norwegian Social Science Data Services (NSD) was notified and approval for the project granted (project No. 30908, 2012). According to the Declaration of Helsinki [33] participants were informed of the background and purpose of the study by way of written and oral information from the project leader. An explanation was given concerning the implications of participation, and voluntary participation was underlined. It was pointed out that participation could be retracted at any point in time and personal details deleted. Written consent to participate in the study was obtained.

\section{Findings}

In the naive reading, all the participants expressed pleasure about moving into independent housing, as well as contentment and relief. Their attention focussed upon managing autonomous living. They shared about feeling unrestricted and managing life on their own. It felt momentous for them to move into their own home where they could make decisions and enjoy a spot of privacy.

Further analysis resulted in the emergence of five major themes: a safe and secure haven, autonomy and responsibility, a variety of friendships, helpful others and meaningful activities.

\subsection{A Safe and Secure Haven}

Prior to moving, many participants positively anticipated leaving their parental home. Subsequent to moving, 
participants expressed a sense of joy and respite. One put it like this: "moving in here and knowing I have secure housing for three years is a tremendous relief".

Several found their new flats to be a place where they could relax. "I can chill out, play music, rest and unwind. Here I can feel at home”. To feel at home included arranging one’s "stuff” in any way one chose. Many of the youth possessed specific ideas about furnishing their flats. Items mentioned as necessities included a decent bed, a TV, a music system and a computer. One pointed to a specific picture on the wall, contending it was his most prized possession, as it portrayed his dream of future employment. Others thankfully spoke of furniture received from family. Several were intent upon making their place homely and keeping it tidy. It was essential for some to have their own kitchen to prepare food of choice.

Some emphasized feeling at home, not only in their new complex, but also in the community. They had grown up in this area; it was a community in which they knew many people, the geography, the history. Others, however, articulated the concept of "home" as a liability. They shared about problematic relationships to home of origin, and connected the concept of home with turbulence. One described it such: "So I've never wanted to go home! Home was turmoil, unrest-I can’t take it...”. A few indicated finding difficulty in relaxing at the new flat. One found it particularly challenging to be alone, and continued to sleep at parent's or friend's homes.

Many revealed gaining additional physical and mental energy after moving in to their own flat. They felt a sense of freedom, managed to be more active, and acquired a drive to resume earlier activities and hobbies. One divulged improved vigour to work with mental health issues:

Moving here has reduced my stress levels by about $90 \%$. I'm not as often down as I used to be. Now I've got a place to recharge $\cdots$ one gets energy to work on things more constructively, like going to a psychologist and stuff!

Several expressed an experience of life coming together and problems dissipating. One emphasized that being included in the project lessened his worries considerably. "I've always had my ups and downs in life, so this here helps me a lot to relax from my burdens”. Both quotations communicate that difficult and unstable life conditions can contribute to mental distress. They also point to the significance of proper housing for mental health.

\subsection{Autonomy and Responsibility}

Prior to moving in, participants shared about dreams of living on their own in new housing. "I can be more independent and try to become an adult $\cdots$ manage everyday living on my own, wash my clothes, make food, with no mum to do things for me". Several emphasized the importance of privacy and autonomy: "It's nice to know that this is a place just for me. I can decide who comes and goes, and then I feel it's my own home”.

Participants with strained relationships to their parents looked forward to moving out of the parental home. They sensed anticipation: "I want out. I want to be as free as a bird to fly wherever I choose. I want to experience creepy things, dangerous things-live life”. Some highlighted the art of mastering independence and gaining competence. They were concerned with the entailing responsibilities, including managing their economy. Some found single living expensive, while others were content to find ways to manage with what they had. "I go through my bills and see how much I have to pay and how much I have left over. I can't afford to buy expensive food ... I do as good as I can to make ends meet”.

\subsection{A Variety of Friendships}

Participants shared that living under the same roof with other project participants inspired them to socialize together. Some expressed this in positive terms. One described the housing complex as "nearly communal living”, since he knew most of the other residents. Two who knew each other previously believed they could assist waking one other in the morning. Another kept in touch with her neighbour via Facebook, posting a message "do you want company?” and receiving an immediate response. Others were not as interested in close contact with fellow residents, preferring to guard their own space.

Living independently made it feasible to resume recreational activities that unstable living conditions had previously hindered. Activities mentioned were weight training, jogging, sports fishing, paintball, horseback riding and keeping pets. Pet-owners shared caring for their animals, emphasizing pets as vital to their new lives.

An important aspect of belonging to the community became maintaining house rules. In second-round inter- 
views, participants told of initial problems with trash and parties, which had since improved. Some had taken charge of shuffling snow, others of keeping trash bins tidy. The use of Facebook to curb loud music proved effective. One explained: "I believe people have acquired more of a sense of responsibility".

A few found it unusual and insecure to share a complex with so many young at risk adults. One expressed concern for fire during parties. Another was anxious about the use of drugs. Several feared outsiders, who while visiting residents, might use illegal drugs on the premises. Some disclosed this as having occurred, and rumours flourished about the dealing of drugs on the housing complex.

Some participants experienced loneliness, with few friends and minimal contact with family. One found it not only positive knowing the others. He desired new friends, i.e., people who did not use drugs. At a party in the complex, he had run across persons with whom he previously did drugs and wished to avoid. Encountering them on the premises made the road reappear rocky, increasing the temptation to resume the use of drugs:

When we had the party here, it brought back memories of previous times, not good ones, either. That's the reason for moving here $\cdots$ a new start. But you don't get a new start when you return to old friends, right? I need in a way new friends. If old friends just turn up at a party here $\cdots$ it can go very wrong then.

There were various attitudes and experiences among participants about social encounters following the move. Some expressed relief at escaping problematic parental relationships, desiring no contact whatsoever. Others emphasized pleasure at being able to invite family. Hosting friends was a plus for many, while a few expressed the need to deny certain persons the right to visit, such as previous boyfriends. For them, having a secure door to lock was a relief.

Several participants expressed a clear sense of belonging to the community, where both their social and public agency networks were located. They appreciated, too, the location of the complex, with short distance to shops and town centre.

\subsection{Helpful Others}

Receiving emotional and practical support from an adult one trusts mattered much for participants. In particular, they emphasized the role of the project leader. Participants found him readily accessible, trustworthy, a dependable adult who represented continuity in the project. Several praised him for quickly meeting challenges connected to issues of housing, work and/or school:

My experience with Jan is that he got things done. If you asked him to do something, it was done in no time flat $\cdots$ It was like-how am I going to manage this economically? And then he'd give me different jobs to do and ring several places. Then he told me the proper questions to ask different support agencies round and about, and he helped me really well with that.

This quote also describes several methods of support employed by the project leader. By giving the participants practical tips concerning whom they themselves could ring and about what to inquire, the leader empowered participants to solve their own problems.

In addition to practical matters, participants accentuated the saliency of care and emotional involvement offered by the project leader. One informant shared this story:

He's a rather easy-going, secure guy and a really good boss for this project. He's the heart of it, and that's really important. Because if you're going to head this kind of project, you've got to put a bit of your soul into it. He's maybe a little old-fashioned, but we laugh and have a cool time at the meetings. We have nearly an hour where we blab. Like, I really have a lot of respect for the man, and when I respect a person, I place them high on my list.

The quote reveals the importance of the project leader as a helpful individual, intensely attentive to the youth.

Those participants with functioning family relationships cited family as their greatest support. Some informants desired regular visits from parents to note their progress. One spoke of his sister as his greatest backer. He could ring her at any time.

Some participants expressed a wish for even greater follow-up than was given, desiring talks about existential issues. A few expressed a concern about other participants' need, having observed that some still struggled with mental health issues and substance abuse after the move. 


\subsection{Meaningful Activities}

Most participants expressed satisfaction and importance linked to education or work training. One participant told that she had begun work as a cleaner. She expressed finding meaning in meeting elderly persons who appreciated her work. Another youth enthusiastically spoke of his work, despite it being temporary. He revelled in the opportunity to try out various jobs, claiming it helped him discover what he really wanted to do. Yet another shared "it feels important to participate in this project, because it means I do what I should be doing. I see more of a point in doing what I'm doing just now. I see several possibilities”. This quote can be understood to mean that participation in the project contributed to easier access to meaningful activities. The person was not alone in forging his way, but received assistance to discover and try out new opportunities.

Not all, however, experienced job training as meaningful. Some feared long-term dependence on government employment assistance, as it might reduce opportunities to acquire regular employment. One disclosed that jobtraining payment was so poor as to not be worth the bother. He fancied instead "a decent job with decent pay".

Some participants articulated specific plans for vocational education. The interviews transmitted a solid impression of long-term housing stimulating them to envision a future embodying education and employment. Some also articulated the significance of secure housing as essential to socializing and to enjoying hobbies and recreational activities.

Gaining a foothold to grip the rocky path towards adulthood is a description intended to express the researchers' holistic understanding of the meaning of the texts. Gaining a foothold on a rocky path illustrates that for youth-at-risk, poor social determinants contribute to impairing their path to confident adulthood, and longterm housing performs as a bulldozer. Housing may not pave the road, but it clears the path sufficiently to allow youth-at-risk to get a grip and traverse over remaining obstacles. By obtaining stable housing with necessary economic support and mental health nursing, the informants (re)established contact with school and work, friends and family. They evolved an identity and envisioned a future hope connected to the process of establishing themselves on their own in the adult world.

\section{Discussion}

The aim of this study is to describe and interpret experiences of participants in gaining a foothold on life as adult citizens. The following discussion concentrates on three themes: facilitating independent living, human support in discovering community, and small steps towards social participation.

\subsection{Facilitating Independent Living}

The findings show that participants, having acquired secure housing and support, experience improved possibilities for further life changes. The significance of "normality", with privacy and a place to house belongings is emphasized in several studies [19] [24] [34]. According to Padgett [24], having one's own home contributes to ontological security through a contribution to the sense of continuity regarding life events. Life appears coherent, stimulating a person to assume greater responsibility for her/his own life.

Our findings imply that participants have procured a sense of greater freedom and self-determination by achieving stable housing. This is supported by Simon's [17] findings. Berzin et al. [34] reported that stable housing became a critical goal for young people leaving foster care, referring to it as the most salient prerequisite for independent living. Wade \& Dickson [19] found secure independent housing to be the factor youth most highly associated with mental well-being, overriding the significance of both education and employment. Viewed from this perspective, adequate and secure housing holds top priority on leveling the road to independent adult living.

The significance of having a home as a place to carry out daily activities is likewise attested to in several studies [35]-[37]. Living in one's own habitat generated a more regulated life for most participants. According to Borg \& Davidson [36], satisfactory housing contributes to improvements in the organization and structure of everyday life, augmenting predictability and a sensibility of control. Gullestad [38] emphasizes that keeping a home helps organize time and living patterns. A person without stabile, secure housing often struggles to think about or plan any future [24]. If life becomes organized, one can explore dreams and plans. This appears to be the case for participants in this study.

The findings also suggest that participants valued choice, both in picking out furnishings and in displaying 
previously stored possessions. Sentimental value receives attention and mention is made of certain items as symbols necessary to create a home [14]. A young participant illustrates this point by sharing that his most cherished possession is a wall hanging he associated with his dream vocation.

Everyday living encompasses mastering everyday tasks. Participants shared a determination to manage personal economy and household duties. Waking up in the morning, getting to work on time, paying bills and caring for animals allow for an association with adulthood, whilst strengthening self-confidence. Participants equated task management with acquired competence, when sharing about life in their own home.

This study also points to how living securely can empower young adults to complete tasks and activities. Such activities are salient to improving health and the quality of life [39]. Furthermore, participants report improved mental health and energy. Other studies emphasize experiences of health benefits for persons with mental health issues by way of obtaining one's own housing [40] [41]. Our findings confirm this positive connection between health, quality of living, and housing.

However, our data indicates that not everyone found respite in the acquisition of housing. Some few reported continued restlessness. Youth-at-risk, with a problematic relationship to childhood, can experience insecurity and lack necessary confidence to live autonomously in order to grasp footing in the adult world. It can prove unfortunate to move a group of acquainted youth-at-risk, some with previous connections to substance abuse, together [42]. This can contribute to insecurity, poor housing maintenance, and hinder integration in the local community.

\subsection{Human Support in Discovering Community}

Our findings show that participants established strong relationships to adult professionals, as is substantiated by the following studies. Wade \& Dickson [19] emphasized a need for special attention and follow-up for youthat-risk. Simon [17] underscored a necessity for housing-support professionals to offer services for developing independent living skills. Darbyshire et al. [43] found that young people saliently valued respectful treatment by professionals. Thompson et al. [44] stressed a need for service providers to be supportive, accommodating and caring. Young adults with adult mentors end up faring better than those without; such relationships are invaluable in compensating support that parents cannot or do not provide [3].

Similar themes deal with trust and respect between client and service provider. The capability to foster trust with youth-at risk is critical for mental health nurses and other professionals [45] [46]. Building relationships based on trust deals, too, with developing social trust, i.e., a belief that people are generally fair and trustworthy [46]. Social trust is deemed important in democratic societies because it leads to an investment in the social order and a commitment to community involvement [46] [47]. It ties to a more positive belief in people and an improved outlook on society. This again stimulates greater social participation and engagement.

\subsection{Steps towards Social Participation}

The results suggested that suitable housing spurs a sense of belonging and social participation. Living together in a complex offered possibilities to create a positive feeling of community, where residents looked after one other, thus contributing to peer support. Demonstrating care, being polite, showing good neighborliness and dreaming of a job that helps others, are all factors in line with descriptions of general social participation [48]. Participation includes involvement, activities, sharing and assuming responsibilities, as well as access and inclusion [27]. With this simple understanding of participation, we maintain that the emerging adults in our study having received and grasped opportunities together with or via professionals - are in the process of developing citizenship.

Housing has permitted these youth a firmer footing, both to develop safe relationships and to gain a sense of community. Our findings suggested that another vital aspect of having a home is that it constituted an arena for contact with friends and family, which again reduced loneliness and strengthened connectedness to the local community. Findings showed the resumption of recreational activities helped participants reestablish friendships and develop new contacts. The young woman, who resumed horse-riding, mentioning budding friendships at the stalls, is one example. Friendships confirm that one is accepted by significant others and belongs to a community [26]. Through relationships with peers, one can acquire new behavior, and learn to understand and cope in social contexts.

Our data disclosed that housing and mental health support seemingly provide a springboard to school and 
work place access. Partaking in education represents participation in the social organization required for the long-term maintenance of society [48]. Holding a job is considered a central obligation of citizenship in modern industrialized society. Similarly, Alexander [49] stresses personal security as closely relating to neighborhood satisfaction, i.e., to feel at home and have a sense of belonging to the local area connects to feelings of safety and community. Living areas located near the city center allow young people to feel connected. This highlights the historically constructed nature of belonging, the sense of being an insider, a part of the culture [25].

All the findings are in line with the health promotion understanding expressed in The Ottawa Charter [21], which emphasizes that material conditions, such as housing, economy and social connectedness stimulate increased quality of living and improved health. It implies a social perspective on health, with focus directed towards a person's external living conditions, rather than towards individual deviations and diagnoses.

\section{Methodological Reflections}

This exploratory, qualitative study was conducted among participants in a single housing program for youth-atrisk in one middle-sized Norwegian municipality. Therefore, it would be imprudent to generalise from this one study to the entire youth-at-risk population. On the other hand, it is reasonable to believe that the knowledge imparted by these youth holds true for others in similar circumstances. Conducting additional interviews with youth with similar life conditions and challenges may enhance the transferability and relevance of the findings in this study.

Another limitation is that only 12 of the 20 youth involved in the project were interviewed. Only two were unwilling to be interviewed; the other six necessitated only limited assistance (in time and breadth) to find housing, and left the project prior to its evaluation.

A strength of the study is the relationships established between the researchers and the participants during the interviews. Most of the interviews mirror trust and openness, as informants shared both positive and negative experiences of their participation in the project, including illegal activities. This again contributed to in-depthfindings that plausibly hold true for others in similar situations.

\section{Implications for Practice Development}

- In order to achieve improvements in housing and housing support for youth-at-risk, issues concerning safety and privacy need to be given priority by mental health nurses and other service providers.

- Youth-at-risk have the right to be heard about their viewpoints concerning housing needs, needs for support and desires for schooling and employment. In order for them to be able to make informed choices, youth need as much information as early as possible.

- Youth-at-risk who are about to move into independent housing necessitate follow-up by persons whom they know and trust. They require an adult who cares and who demonstrates such care, thereby deserving their trust.

- Youth-at-risk require assistance in developing skills to move towards fully independent living. This includes providing counselling and advice, signposting relevant professional services and helping them gain an increased understanding of housing rights and obligations. Specifically this implies services that are coordinated, demonstrating continuity over time, and developed together with the youth-in-question, so as to meet their needs relating to family, peers, schools, and other, individual challenges [cf. 8].

- It is important to evaluate the benefits and drawbacks of housing youth-at-risk in the same complex. While economically profitable, the social hitches of close proximity to previous drug cohorts can cost society more than it saves. For the large majority of young homeless individuals, housing in independent scattered housing with floating mental health and social support remains the most favorable option.

\section{Conclusions}

The findings of this study appear to confirm positive connections among health, the quality of living, and housing. Additionally, a sense of belonging, both to the smaller community of residents and to family and the community at large, emerges as vital factors in the move towards maturity. Possessing supportive professional relationships appear pertinent to clear rubble on the path to adulthood. Meaningful activities, vocational as well as recreational, seemingly boost the confidence necessary for youth-at-risk to emerge as social participants in the 
society- at-large.

Gaining a foothold on life requires removing, chiseling, or in some cases side-stepping the rock-strewn life path that youth-at-risk must negotiate in coming to grips with adulthood. It involves as well, a society that offers coordinated assistance. Projects such as Good Start deserve recognition and repetition. We have no youth to lose.

\section{References}

[1] Arnett, J.J. and Hughes, M. (2012) Adolescence and Emerging Adulthood: A Cultural Approach. Pearson Press, Harlow.

[2] De Marco, A.C. and Berzin, S.C. (2008) The Influence of Family Economic Status on Home-Leaving Patterns during Emerging Adulthood. Families in Society: The Journal of Contemporary Social Services, 89, 208-218. http://dx.doi.org/10.1606/1044-3894.3736

[3] Settersten, R.A. and Ray, B. (2010) What's Going on with Young People Today? The Long and Twisting Path to Adulthood. The Future of Children, 20, 19-41. http://dx.doi.org/10.1353/foc.0.0044

[4] Norwegian Social Research (NOVA) (2014) Ungdata—nasjonaleresultater 2013 (Youth Data—National Results 2013) Report No. 10/14, Norwegian Social Research Institute, Oslo. (In Norwegian)

[5] United Nations Development Programme (2014) Sustaining Human Progress: Reducing Vulnerabilities and Building Resilience. Human Development Report 2014. http://hdr.undp.org/en

[6] NOU (2009) Det du gjør, gjør det helt. Bedre samordning av tjenester for utsatte barn og unge (Whatever You Do, Do It Well. Better Coordination of Services for Children and Adolescents). Norwegian Official Report, Ministry of Children, Equality and Social Inclusion. (In Norwegian)

[7] Patel, V., Flisher, A.J., Hetrick, S. and McGorry, P. (2007) Mental Health of Young People: A Global Public-Health Challenge. Lancet, 369, 1302-1313. http://dx.doi.org/10.1016/S0140-6736(07)60368-7

[8] Ungar, M., Liebenberg, L. and Ikeda, J. (2014) Young People with Complex Needs: Designing Coordinated Interventions to Promote Resilience across Child Welfare, Juvenile Corrections, Mental Health and Education Services. British Journal of Social Work, 44, 675-693. http://dx.doi.org/10.1093/bjsw/bcs147

[9] Singh, M.P., Paul, M., Ford, T., Kramer, T., Weaver, T., McLaren, S., et al. (2010) Process, Outcome and Experience of Transition from Child to Adult Mental Healthcare: Multiperspective Study. The British Journal of Psychiatry, 197, 305-312. http://dx.doi.org/10.1192/bjp.bp.109.075135

[10] NOU (2011) Rom for alle—sosialboligpolitikk for framtida (Room for Everyone—Social Housing Policy for the Future). Norwegian Official Report, Ministry of Local Government and Modernization. (In Norwegian)

[11] Smetana, J.G., Campione-Barr, N. and Metzger, A. (2006) Adolescent Development in Interpersonal and Societal Contexts. Annual Review of Psychology, 57, 255-284. http://dx.doi.org/10.1146/annurev.psych.57.102904.190124

[12] Costello, E.J., Egger, H. and Angold, A. (2005) 10-Year Research Update Review: The Epidemiology of Child and Adolescent Psychiatric Disorders: I. Methods and Public Health Burden. Journal of American Academy of Child \& Adolescent Psychiatry, 44, 972-986. http://dx.doi.org/10.1097/01.chi.0000172552.41596.6f

[13] Curtis, S., Pain, R., Fuller, S., Khatib, Y., Rotnon, C., Standsfeld, S. and Daya, S. (2013) Neighbourhood Risk Factors for Common Mental Disorders among Young People Aged 10-20 Years: A Structured Review of Quantitative Research. Health and Place, 20, 81-90. http://dx.doi.org/10.1016/j.healthplace.2012.10.010

[14] Winther, I.W. (2006) Hjemlighed_Kulturfænomenologiske studier (Homeliness_Culture Phenomenological Studies). Danmarks Pædagogiske Universitets Forlag, Copenhagen. (In Danish)

[15] Saunders, P. (1989) The Constitution of the "Home” in Contemporary English Culture. Housing Studies, 4, 177-192. http://dx.doi.org/10.1080/02673038908720658

[16] Rambøll Management Consulting (2010) Kunnskapsoversikt over forskning om vanskeligstilte på boligmarkedet 2004-2010 (An Overview of the Research Concerning Those Having Difficulty Obtaining Housing from 2004-2010). Husbanken. (In Norwegian) www.husbanken.no

[17] Simon, A. (2008) Early Access and Use of Housing: Care Leavers and Other Young People in Difficulty. Child and Family Social Work, 13, 91-100.

[18] Hodgson, K.J., Shelton, K.H., van den Bree, M.B. and Los, F.J. (2013) Psychopathology in Young People Experiencing Homelessness: A Systematic Review. American Journal of Public Health, 103, e24-e37. http://dx.doi.org/10.2105/ajph.2013.301318

[19] Wade, J. and Dixon, J. (2006) Making a Home, Finding a Job: Investigating Early Housing and Employment Outcomes for Young People Leaving Care. Child and Family Social Work, 11, 199-208.

http://dx.doi.org/10.1111/j.1365-2206.2006.00428.x 
[20] WHO (2012) Social Determinants of Health, Report by the Secretariat. http://www.who.int/social_determinants/B_132_14-en.pdf?ua=1

[21] WHO (1986) The Ottawa Charter for Health Promotion. 1st International Conference on Health Promotion, Ottawa, 21 November 1986. http://www.who.int/healthpromotion/conferences/previous/ottawa/en/index1.html

[22] WHO (2007) People-Centred Health Care: A Policy Framework. World Health Organization, Geneva.

[23] Martinsen, K. (2006) Care and Vulnerability. Akribe, Oslo.

[24] Padgett, D.K. (2007) There’s No Place Like (a) Home: Ontological Security among Persons with Serious Mental Illness in the United States. Social Science \& Medicine, 64, 1925-1936. http://dx.doi.org/10.1016/j.socscimed.2007.02.011

[25] Fields, D. (2011) Emotional Refuge? Dynamics of Place and Belonging among Formerly Homeless. Emotion, Space and Society, 4, 258-267. http://dx.doi.org/10.1016/j.emospa.2010.09.002

[26] Arnett, J.J. (2004) Emerging Adulthood: The Winding Road from the Late Teens through the Twenties. Oxford University Press, Oxford.

[27] European Youth Centre (2008) Have Your Say! Manual on the Revised European Charter on the Participation of Young People in Local and Regional Life. Council of Europe Publishing, Brussels.

[28] Ministry of Local and Regional Government (2011) Forskrift om kompetansetilskudd til boligsosialt arbeid fra Husbanken (Regulations concerning Grants for Social Housing). https://lovdata.no/dokument/SF/forskrift/2011-02-23-193

[29] Miller, W.L. and Crabtree, B.F. (1999) Depth Interviewing. In: Crabtree, B.F. and Miller, W.L., Eds., Doing Qualitative Research, Sage, Thousand Oak, 89-107.

[30] Ricoeur, P. (1976) Interpretation Theory: Discourse and the Surplus of Meaning. Texas Christian University Press, Forth Worth.

[31] Kvale, S. and Brinkman, S. (2011) Interview. Introduction til et håndverk. Hans Reizel, København. (In Danish)

[32] Lindseth, A. and Norberg, A. (2004) A Phenomenological Hermeneutical Method for Researching Lived Experience. Scandinavian Journal of Caring Sciences, 18, 145-153. http://dx.doi.org/10.1111/j.1471-6712.2004.00258.x

[33] World Medical Association (2008) Declaration of Helsinki. Ethical Principles for Medical Research Involving Human Subjects. WHO, Geneva. www.wma.net/en/30publications/10policies/b3/

[34] Berzin, S.C., Singer, E. and Hokanson, K. (2014) Emerging versus Emancipating: The Transition to Adulthood for Youth in Foster Care. Journal of Adolescent Research, 29, 616-638. http://dx.doi.org/10.1177/0743558414528977

[35] Borg, M., Sells, D., Topor, A., Mezzina, R., Marin, I. and Davidson, L. (2005) What Makes a House a Home: The Role of Material Resources in Recovery from Severe Mental Illness. American Journal of Psychiatric Rehabilitation, 8, 243-256. http://dx.doi.org/10.1080/15487760500339394

[36] Borg, M. and Davidson, L. (2008) The Nature of Recovery as Lived in Everyday Experience. Journal of Mental Health, 17, 129-140. http://dx.doi.org/10.1080/15487760500339394

[37] Ness, O., Borg, M. and Davidson, L. (2014) Facilitators and Barriers in Dual Recovery: A Literature Review of FirstPerson Perspectives. Advances in Dual Diagnosis, 7, 107-117. http://dx.doi.org/10.1108/ADD-02-2014-0007

[38] Gullestad, M. (1989) Kultur og hverdagsliv (Culture and Everyday Life). Universitetsforlaget, Oslo. (In Norwegian)

[39] Norwegian Directorate of Health (2011) Nasjonal faglig retningslinje for utredning, behandling og oppfølging av personer med samtidig ruslidelse og psykisk lidelse-ROP-lidelser. Helsedirektoratet, Oslo. (In Norwegian)

[40] Kyle, T. and Dunn, J.R. (2008) Effects of Housing Circumstances on Health, Quality of Life and Healthcare Use for People with Severe Mental Illness: A Review. Health \& Social Care in the Community, 16, 1-15. http://dx.doi.org/10.1111/j.1365-2524.2007.00723.x

[41] Wright, P.A. and Kloos, B. (2007) Housing Environment and Mental Health Outcomes: A Levels of Analysis Perspective. Journal of Environmental Psychology, 27, 79-89. http://dx.doi.org/10.1016/j.jenvp.2006.12.001

[42] Bild, M. and Gerdner, A. (2006) Socially Excluding Housing Support to Homeless Substance Abusers: Two Swedish Case Studies of Special Category Housing. International Journal of Social Welfare, 15, 162-171. http://dx.doi.org/10.1111/j.1468-2397.2006.00385.x

[43] Darbyshire, P., Muir-Cochrane, E., Fereday, J., Jureidini, J. and Drummond, A. (2006) Engagement with Health and Social Care Services: Perceptions of Homeless Young People with Mental Health Problems. Health and Social Care in the Community, 14, 553-562. http://dx.doi.org/10.1111/j.1365-2524.2006.00643.x

[44] Thompson, S.J., Ryan, T.N., Montgomery, K.L., Lippman, A., Bender, K. and Ferguson, K. (2013) Perceptions of Resiliency and Coping: Homeless Young Adult Speak Out. Youth Society, 48, 58-76. 
[45] Ulager, J., Pearson, A., Tomescu, O., Hill, C., Auerswald, C. and Ginsburg, K. (2005) “Why Should I Tell You?” Homeless Youth Share What It Takes for Professionals to Earn Their Trust. Journal of Adolescent Health, 36, 133-134. http://dx.doi.org/10.1016/j.jadohealth.2004.11.080

[46] Flanagan, C.A. and Stout, M. (2010) Developmental Patterns of Social Trust between Early and Late Adolescence: Age and School Climate Effects. Journal of Research on Adolescence, 20, 748-773. http://dx.doi.org/10.1111/j.1532-7795.2010.00658.x

[47] Flanagan, C.A., Gill, S. and Gallay, L.S. (2005) Social Participation and Social Trust in Adolescence: The Importance of Heterogeneous Encounters. In: Omoto, A., Ed., Processes of Community Change and Social Action, Earlbaum, Mahwah, 149-166.

[48] Smith, N., Lister, R., Middelton, S. and Cox, L. (2005) Young People as Real Citizens: Towards an Inclusionary Understanding of Citizenship. Journal of Youth Studies, 8, 425-443. http://dx.doi.org/10.1080/13676260500431743

[49] Alexander, C.F. (2008) Safety, Fear and Belonging: The Everyday Realities of Civic Identity Formation in Fenham. ACME: An International E-Journal for Critical Geographies, 7, 173-198. 